\title{
Long term exposure to ambient air pollution and incidence of acute coronary events: prospective cohort study and meta-analysis in 11 European cohorts from the ESCAPE Project
}

Giulia Cesaroni senior researcher ${ }^{1}$, Francesco Forastiere research director ${ }^{1}$, Massimo Stafoggia senior researcher ${ }^{1}$, Zorana J Andersen associate professor in epidemiology ${ }^{23}$, Chiara Badaloni research fellow ${ }^{1}$, Rob Beelen senior researcher ${ }^{4}$, Barbara Caracciolo researcher ${ }^{56}$, Ulf de Faire senior professor of cardiovascular epidemiology ${ }^{7}$, Raimund Erbel professor ${ }^{8}$, Kirsten T Eriksen researcher ${ }^{2}$, Laura Fratiglioni professor in geriatric epidemiology ${ }^{5910}$, Claudia Galassi medical epidemiologist ${ }^{11}$, Regina Hampel research fellow ${ }^{12}$, Margit Heier research fellow ${ }^{1213}$, Frauke Hennig research fellow ${ }^{14}$, Agneta Hilding researcher ${ }^{15}$, Barbara Hoffmann professor ${ }^{14}{ }^{16}$, Danny Houthuijs senior researcher ${ }^{17}$, Karl-Heinz Jöckel professor ${ }^{18}$, Michal Korek doctoral student ${ }^{7}$, Timo Lanki chief researcher $^{19}$, Karin Leander researcher ${ }^{7}$, Patrik K E Magnusson professor ${ }^{20}$, Enrica Migliore epidemiologist $^{11}$, Caes-Göran Ostenson professor ${ }^{15}$, Kim Overvad professor ${ }^{2122}$, Nancy L Pedersen professor of genetic epidemiology ${ }^{20}$, Juha Pekkanen J professor ${ }^{19}$, Johanna Penell researcher ${ }^{7}$, Göran Pershagen professor ${ }^{7}$, Andrei Pyko research fellow ${ }^{7}$, Ole Raaschou-Nielsen head of research group $^{2}$, Andrea Ranzi project manager in environmental epidemiology ${ }^{23}$, Fulvio Ricceri research fellow $^{24}$, Carlotta Sacerdote medical epidemiologist ${ }^{11}$, Veikko Salomaa research professor ${ }^{25}$, Wim Swart researcher ${ }^{17}$, Anu W Turunen researcher ${ }^{19}$, Paolo Vineis professor in epidemiology ${ }^{24}{ }^{26}$, Gudrun Weinmayr research associate ${ }^{1427}$, Kathrin Wolf research fellow ${ }^{12}$, Kees de Hoogh senior research officer ${ }^{26}$, Gerard Hoek associate professor ${ }^{4}$, Bert Brunekreef professor ${ }^{428}$, Annette Peters professor $^{12}$

${ }^{1}$ Department of Epidemiology, Lazio Regional Health Service, 00198 Rome, Italy; ${ }^{2}$ Danish Cancer Society Research Center, 2100 Copenhagen, Denmark; ${ }^{3}$ Center for Epidemiology and Screening, Department of Public Health, University of Copenhagen, 1014 Copenhagen, Denmark; ${ }^{4}$ Institute for Risk Assessment Sciences, Utrecht University, PO Box 80178, 3508 TD Utrecht, Netherlands; ${ }^{5}$ Aging Research Center, Department of Neurobiology, Care Sciences and Society, Karolinska Institutet, S-113 30 Stockholm, Sweden; ${ }^{6}$ Stress Research Institute, Stockholm University, SE-106 91 Stockholm, Sweden; ${ }^{7}$ Institute of Environmental Medicine, Karolinska Institutet, Box 210 SE-171 77 Stockholm, Sweden; ${ }^{8}$ West German Heart Center, University Hospital of Essen, 45122 Essen, Germany; ${ }^{9}$ Stockholm Gerontology Research Center, 11330 Stockholm, Sweden; ${ }^{10}$ Division of Clinical Geriatrics, Karolinska University Hospital, SE-141 86 Stockholm, Sweden; ${ }^{11}$ Unit of Cancer Epidemiology, "Città della Salute e della Scienza" Hospital, University of Turin, and Center for Cancer Prevention Piemonte, 10126 Turin, Italy; ${ }^{2}$ Helmholtz Zentrum München, German Research Center for Environmental Health, Institute of Epidemiology II, 85764 Neuherberg, Germany; ${ }^{13}$ Central Hospital of Augsburg, MONICA/KORA Myocardial Infarction Registry, D-86156 Augsburg, Germany; ${ }^{14}$ IUF-Leibniz Research Institute for Environmental Medicine, 40225 Düsseldorf, Germany; ${ }^{15}$ Department of Molecular Medicine and Surgery, Karolinska Institutet, Karolinska University Hospital, SE-171 77 Stockholm, Sweden; ${ }^{16}$ Medical Faculty, University of Düsseldorf, 40225 Düsseldorf, Germany; ${ }^{17}$ National Insititute for Public Health and the Environment, PO Box 1, 3720 BA Bilthoven, Netherlands; ${ }^{18}$ Institute for Medical Informatics, Biometry and Epidemiology, University Hospital of Essen, D-45122 Essen, Germany; ${ }^{19}$ National Institute for Health and Welfare "THL", Department of Environmental Health, PO Box 95, FI-70701 Kuopio, Finland; ${ }^{20}$ Department of Medical Epidemiology and Biostatistics, Karolinska Institutet, SE-171 77 Stockholm, Sweden; ${ }^{21}$ Section for Epidemiology, Department of Public Health, Aarhus University, DK-8000 Aarhus, Denmark; ${ }^{22}$ Department of Cardiology, Cardiovascular Research Center, Aalborg University Hospital, DK-9000 Aalborg, Denmark; ${ }^{23}$ Environmental Health Reference Centre-Regional Agency for Environmental Prevention of Emilia-Romagna, 41121 Modena, Italy; ${ }^{24}$ Molecular and Genetic Epidemiology Unit, HuGeF-Human Genetics Foundation-Turin, 10126 Turin, Italy; ${ }^{25} \mathrm{THL}-\mathrm{National}$ 
Institute for Health and Welfare, Department of Chronic Disease Prevention, POB 30, FI-00271 Helsinki, Finland; ${ }^{26}$ MRC-HPA Centre for Environment and Health, Department of Epidemiology and Biostatistics, Imperial College London, St Mary's Campus, London W2 1PG, UK; ${ }^{27}$ Institute of Epidemiology and Medical Biometry, Ulm University, 89069 Ulm, Germany; ${ }^{28}$ Julius Center for Health Sciences and Primary Care, University Medical Center Utrecht, PO Box 85500, 3508 GA Utrecht, Netherlands

\begin{abstract}
Objectives To study the effect of long term exposure to airborne pollutants on the incidence of acute coronary events in 11 cohorts participating in the European Study of Cohorts for Air Pollution Effects (ESCAPE).

Design Prospective cohort studies and meta-analysis of the results. Setting Cohorts in Finland, Sweden, Denmark, Germany, and Italy. Participants 100166 people were enrolled from 1997 to 2007 and followed for an average of 11.5 years. Participants were free from previous coronary events at baseline.
\end{abstract}

Main outcome measures Modelled concentrations of particulate matter $<2.5 \mu \mathrm{m}\left(\mathrm{PM}_{2.5}\right), 2.5-10 \mu \mathrm{m}\left(\mathrm{PM}_{\text {coarse }}\right)$, and $<10 \mu \mathrm{m}\left(\mathrm{PM}_{10}\right)$ in aerodynamic diameter, soot ( $\mathrm{PM}_{2.5}$ absorbance), nitrogen oxides, and traffic exposure at the home address based on measurements of air pollution conducted in 2008-12. Cohort specific hazard ratios for incidence of acute coronary events (myocardial infarction and unstable angina) per fixed increments of the pollutants with adjustment for sociodemographic and lifestyle risk factors, and pooled random effects meta-analytic hazard ratios.

Results 5157 participants experienced incident events. A $5 \mu \mathrm{g} / \mathrm{m}^{3}$ increase in estimated annual mean $\mathrm{PM}_{2.5}$ was associated with a $13 \%$ increased risk of coronary events (hazard ratio $1.13,95 \%$ confidence interval 0.98 to 1.30 ), and a $10 \mu \mathrm{g} / \mathrm{m}^{3}$ increase in estimated annual mean $\mathrm{PM}_{10}$ was associated with a $12 \%$ increased risk of coronary events (1.12, 1.01 to 1.25 ) with no evidence of heterogeneity between cohorts. Positive associations were detected below the current annual European limit value of $25 \mu \mathrm{g} / \mathrm{m}^{3}$ for $\mathrm{PM}_{2.5}\left(1.18,1.01\right.$ to 1.39 , for $5 \mu \mathrm{g} / \mathrm{m}^{3}$ increase in $\left.\mathrm{PM}_{2.5}\right)$ and below $40 \mu \mathrm{g} / \mathrm{m}^{3}$ for $\mathrm{PM}_{10}\left(1.12,1.00\right.$ to 1.27 , for $10 \mu \mathrm{g} / \mathrm{m}^{3}$ increase in $\mathrm{PM}_{10}$ ). Positive but non-significant associations were found with other pollutants.

Conclusions Long term exposure to particulate matter is associated with incidence of coronary events, and this association persists at levels of exposure below the current European limit values.

\section{Introduction}

According to the recent report on the Global Burden of Disease, throughout the world particulate air pollution is estimated to cause 3.1 million deaths a year and $22 \%$ of disability adjusted life years (DALY) due to ischaemic heart disease. ${ }^{1}$ Several cohort studies have reported that long term exposure to air pollution is associated with mortality, in particular cardiovascular mortality. ${ }^{2-13}$ The evidence of an effect on incidence of cardiovascular events - that is, acute myocardial infarction and unstable angina-is less consistent and requires further investigations. ${ }^{12-15}$

In the European Union the current annual limit for particulate matter $<2.5 \mu \mathrm{m}\left(\mathrm{PM}_{2.5}\right)$ is $25 \mu \mathrm{g} / \mathrm{m}^{3}$, which is far above that implemented in the United States $\left(12 \mu \mathrm{g} / \mathrm{m}^{3}\right)$. One obstacle in the European standard setting process in the past had been that the available estimates of the exposure-response associations of particulate matter were primarily based on studies conducted in North America. ${ }^{3-12}$ In response, the ESCAPE Study (European
Study of Cohorts for Air Pollution Effects) was conducted between 2008 and 2012 to quantify the associations between exposures and health outcomes by using standardised methods for assessment of exposure and data from existing cohort studies. ${ }^{16} 17$

We estimated the association between long term exposure to particulate matter $<2.5 \mu \mathrm{m}\left(\mathrm{PM}_{2.5}\right), 2.5-10 \mu \mathrm{m}$ (coarse), $<10 \mu \mathrm{m}$ $\left(\mathrm{PM}_{10}\right)$ in aerodynamic diameter, soot $\left(\mathrm{PM}_{2.5}\right.$ absorbance), nitrogen oxides $\left(\mathrm{NO}_{\mathrm{x}}\right.$ and $\left.\mathrm{NO}_{2}\right)$, and traffic indicators and the incidence of coronary events. We evaluated effect modification by several individual characteristics, and we investigated the exposure-response relations of the pollutants below selected thresholds.

\section{Methods \\ Design and population}

This study is an analysis of cohort data obtained by ESCAPE to investigate the long term effects of exposure to air pollution on human health in Europe and a meta-analysis of the cohort specific results. The present study included 11 European cohorts from five countries with information about incident cases of acute coronary events and the most important potential confounders. The cohorts were in Finland (FINRISK) ${ }^{18}$; Sweden (the Swedish National Study on Aging and Care in Kungsholmen (SNAC-K), the Screening Across the Lifespan Twin Study, (SALT), the 60 year olds study, and the Stockholm Diabetes Prevention Program study (SDPP)) ${ }^{19-22}$; Denmark (the Danish Diet, Cancer and Health cohort study $[\mathrm{DCH}])^{23}$; Germany (the Heinz Nixdorf Recall Study (HNR), the Cooperative Health Research in the Augsburg Region (KORA) $)^{24} 25$; and Italy (the European Prospective Investigation into Cancer and Nutrition in Turin (Epic-Turin), the International Study on Asthma and Allergies in Childhood in Turin and Rome (parents of representative samples of children participating in SIDRIA-Turin and SIDRIA-Rome)). ${ }^{26}{ }^{27}$ These were all centres included in the ESCAPE intensive monitoring programme for particulate matter and nitrogen oxides. ${ }^{28}{ }^{29}$ Table 1 shows specific settings, periods of recruitment, and person years at risk $\Downarrow$. With the exception of the Italian cohorts, all the cohorts enrolled representative samples of the adult population for the age groups considered in the single studies. Additional information on each cohort is presented in the appendix.

\section{Outcome definition}

For nine out of 11 cohorts, information on coronary events was derived by record linkage procedures with hospital discharge and mortality registries. We selected international classification of diseases (ICD) codes for "acute myocardial infarction" or "other acute and sub-acute forms of ischemic heart disease" (ICD-9-CM codes: 410, 411; ICD-10 codes: I21, I23, I20.0, I24) in principal diagnoses of hospital discharges. We also considered as incident cases those people who died outside 
hospital from ischaemic heart diseases, according to the death certificates (ICD-9: 410-414; ICD-10: I20-I25) and had no evidence of hospital admission for ischaemic heart disease in the 28 days before death and no evidence of admission for any cause in the two days before death. To identify incident cases, we excluded those who had had an acute coronary event or cerebrovascular event previously (previous admission to hospital with principal or secondary diagnoses with ICD-9 codes 410, 411, 430, 431, 434, 436 and ICD-10 codes I21, I23, I20.0, I24, I61, I63, I64). The reference period to evaluate previous events varied across the cohorts, with the minimum of three years in the two SIDRIA cohorts and all lifelong history for the KORA cohort. For the HNR study, incident cases were adjudicated by an independent end point committee based on medical records. ${ }^{24}$ For the KORA cohort, incident cases were determined by interview and medical history and validated through linkage with the myocardial infarction register. ${ }^{25}$

\section{Exposure to air pollution}

Exposure to air pollution in each area was estimated following a standard methods developed for the ESCAPE project and described elsewhere. ${ }^{28}{ }^{29}$ Briefly, for each area under study, particulate matter of varying sizes measured in $\mu \mathrm{m}$ (shown as subscript) - that is, $\mathrm{PM}_{10}$, coarse $\mathrm{PM}, \mathrm{PM}_{2.5}$, and $\mathrm{PM}_{2.5}$ absorbance (blackness of the $\mathrm{PM}_{2.5}$ exposed filter, determined by measurement of light reflectance as a marker for soot and black carbon)—was measured in 20 sites, and nitrogen oxides were measured in 40 sites in three separate two week periods (to cover different seasons) over one year (between 2008 and 2011). For each site, results from the three measurements were averaged to estimate the annual average, with adjustment for temporal variation by using a centrally located background reference site, which was operated for a whole year. ${ }^{30} 31$ By using several traffic and land use variables, we developed area specific land use regression (LUR) models to explain the spatial variation of each measured pollutant. These models were then used to estimate concentrations of air pollution at each participant's residential address. Geographical variables typically evaluated include altitude, population density, industrial land use, green space, and traffic flows variables. ${ }^{30}{ }^{31}$ In addition to concentrations of pollutants, we considered two traffic variables at the participant's residence: traffic intensity on the nearest road (vehicles/day) and traffic load on major roads in a $100 \mathrm{~m}$ buffer (vehicles $\times \mathrm{m} /$ day), defined as the sum of traffic intensity on roads with $>5000$ vehicles/day multiplied by the length of those roads in a $100 \mathrm{~m}$ buffer. To validate the models, we used the leave one out cross validation method - that is,

systematically subtracting each of the monitoring points from the model one by one, and then comparing the predicted value for each monitoring location with the measured level at the location without using this measurement in the development of the model. ${ }^{30} 31$

\section{Covariates}

All cohorts had a common set of potential confounders and effect modifiers at baseline: marital status (coded as single, married/living with partner, divorced/separated, widowed; for the SDPP cohort only the binary variable "living with partner" was available; for SIDRIA-Rome all participants were living as couples at baseline), education (primary school or less, up to secondary school or equivalent, university degree and more), occupation (employed, unemployed, homemaker/housewife, retired), smoking status (current, former, never), duration of smoking (years), smoking intensity (cigarettes/day), hypertension, and diabetes. Most cohorts had information on additional cardiovascular risk factors such as body mass index (BMI; coded as $<25,25-29, \geq 30$ ), physical activity ( $<1$ hour/week, about 1 hour/week, $>2$ hours/week), alcohol consumption (never, 1-3 drinks/week, 3-6 drinks/week, >6 drinks/week), and three cohorts had information on use of drugs for hormone replacement therapy. Four of 11 cohorts had data on cholesterol concentrations. Ten of 11 cohorts had data on noise exposure, estimated at the residential addresses from European noise exposure assessment in 2007, and we used an eight class categorical variable of $5 \mathrm{~dB}$ of exposure from $45 \mathrm{~dB}$ to $75 \mathrm{~dB}$ and more (see appendix). Each cohort also used an area based socioeconomic status indicator because socioeconomic indicators at the area level are predictors of morbidity, access to care, and lifestyle risk factors in addition to individual socioeconomic characteristics. ${ }^{32}$

\section{Statistical analyses}

To evaluate the association between exposure to air pollution and incidence of coronary events we performed the analyses in two stages. Firstly, we analysed each cohort using a common protocol for confounders, outcomes, and statistical modelling. We used Cox proportional hazards regression models (hazard ratios) with age as the time scale. A script with statistical code was provided to all cohort specific analysts. The results were evaluated centrally at the Department of Epidemiology in Rome. Secondly, we carried out a random effects meta-analysis to pool results. ${ }^{33} \mathrm{We}$ calculated $\mathrm{I}^{2}$ statistics and $\mathrm{P}$ values for $\chi^{2}$ test from Cochran's Q to quantify the heterogeneity among studies. ${ }^{34}$

We first estimated hazard ratios adjusted for age, sex, and year of enrolment only (model 1), then adjusted for a common set of individual covariates (marital status, education, occupation, smoking status, smoking duration, and smoking intensity; model 2), and then adjusted for area based socioeconomic status indicators (model 3). When investigating the effects of traffic variables we also adjusted all models for background $\mathrm{NO}_{2}$ levels . We estimated the effects of exposure to air pollution using fixed increments of pollutants $\left(20 \mu \mathrm{g} / \mathrm{m}^{3}\right.$ for $\mathrm{NO}_{\mathrm{x}}, 10 \mu \mathrm{g} / \mathrm{m}^{3}$ for $\mathrm{PM}_{10}$ and $\mathrm{NO}_{2}, 5 \mu \mathrm{g} / \mathrm{m}^{3}$ for $\mathrm{PM}_{2.5}$ and $\mathrm{PM}_{\text {coarse }}, 10^{-5} / \mathrm{m}$ for $\mathrm{PM}_{2.5}$ absorbance).

We performed several sensitivity analyses to deal with potential sources of bias and to consider the confounding role of additional cardiovascular risk factors. Firstly, we adjusted for possible intermediate variables (diabetes, hypertension) available in all the cohorts; then for physical activity, alcohol consumption, and BMI (available in eight cohorts); finally we added to previously mentioned factors the cholesterol concentration (available in four cohorts). We then analysed the role of living in low/high urbanised settings, of noise exposure, and of residential stability (restricting the analysis to those living at the same baseline address during the follow-up). We stratified the Cox model 3 for predictors that did not meet the proportionality hazard assumption. We analysed the influential role of the largest cohort by excluding the DCH study from the analysis. Finally, we evaluated the role of the performance of land use regression models, stratifying cohorts by cross validation $\mathrm{R}^{2}>$ or $\leq 60 \%$.

To explore the effect of clustering by area of residence in the association between exposure and mortality-that is, residents in the same area usually share similar characteristics (socioeconomic status, health, access to services) and have similar environmental and air conditions-we performed a frailty model to measure the role each area played. ${ }^{4}$

We evaluated potential effect modification by adding to model 3 an interaction term of exposure and one effect modifier at a 
time (sex, educational level, smoking status, BMI, hypertension, and residence in low or high urbanised settings). We used the likelihood ratio test to compare the models with and without interaction terms. For age during follow-up, we estimated effect modification by adding an interaction term between exposure and a time dependent categorical variable indicating age group $(<60,60-74,>75)$.

To provide information about the health effects below specific threshold values $\left(20,30\right.$, and $40 \mu \mathrm{g} / \mathrm{m}^{3}$ for $\mathrm{PM}_{10}$, and 15,20 , and $25 \mu \mathrm{g} / \mathrm{m}^{3}$ for $\mathrm{PM}_{2.5}$ ), we studied the effect of fixed increments of $\mathrm{PM}_{2.5}$ and $\mathrm{PM}_{10}$ among people with air pollution concentrations at residences only below these thresholds.

We used STATA software (versions 10, 11, and 12) for all the analyses, with the exception of frailty models for which we used $\mathrm{R}$ (www.r-project.org).

\section{Results}

Table 1 shows a summary description of the 11 European cohorts $\Downarrow$. Table 2 shows individual characteristics of participants $\Downarrow$ and table 3 their exposures to air pollution $\Downarrow$. Additional characteristics of the participants are provided in table $4 \Downarrow$. The enrolment period covered 15 years, and the average follow-up was 11.5 years. The participating cohorts varied in characteristics, availability of data on covariates, and levels of exposure. The proportion of participants included in the study ranged from $82.4 \%$ to $99.3 \%$ of the original cohorts (overall $93.1 \%$ ), after exclusion of missing values on any of the covariates in model 3 . There were no differences in exposure levels between included and excluded participants. Among 100 166 participants included in the study and followed for 1154 386 person years, there were 5157 incident cases. The average $\mathrm{PM}_{2.5}$ level at residence ranged from $7.3 \mu \mathrm{g} / \mathrm{m}^{3}$ in Sweden $(\mathrm{SD}=1.3)$ to $31.0 \mu \mathrm{g} / \mathrm{m}^{3}(\mathrm{SD}=1.7)$ in northern Italy, and all other pollutants had similar patterns. All exposure models had good performance $\left(\mathrm{R}^{2} \geq 0.61\right)$, and the prediction ability of models for nitrogen dioxides (based on a larger number of measurements sites) was slightly higher than those of particulate models.

Table $5 \Downarrow$ shows the pooled hazard ratios with $95 \%$ confidence intervals for incidence of coronary events for fixed increments of all pollutants. We observed the strongest association for $\mathrm{PM}_{10}$. While in model 1 (adjusted for age, sex, and calendar period) all particulate matter indicators were strongly associated with incidence of coronary events, when we adjusted for marital status, education, occupation, smoking status, smoking duration, smoking intensity, and socioeconomic area indicator (model 3), only $\mathrm{PM}_{10}$ showed a significant association (hazard ratio 1.12, $95 \%$ confidence interval 1.01 to 1.25 , for each $10 \mu \mathrm{g} / \mathrm{m}^{3}$ increase). There was also an association for $\mathrm{PM}_{2.5}(1.13,0.98$ to 1.30 , for each $5 \mu \mathrm{g} / \mathrm{m}^{3}$ increase) and for coarse particles, whereas only small positive associations were found for nitrogen oxides. There was no evidence of an effect of traffic variables. There was no evidence of statistical heterogeneity between the cohort specific effect estimates $\left(\mathrm{I}^{2}<5 \%\right)$. The figure $\Downarrow$ shows the forest plots of $10 \mu \mathrm{g} / \mathrm{m}^{3} \mathrm{PM}_{10}$ and $5 \mu \mathrm{g} / \mathrm{m}^{3} \mathrm{PM}_{2.5}$ increments (model 3).

Table $6 \Downarrow$ shows the results of the sensitivity analyses for $\mathrm{PM}_{10}$ and $\mathrm{PM}_{2.5}$ from the base model (model 3), reporting the number of cohorts and participants included in each analysis. Overall, there were only a few marginal changes in the effect estimates across the various models, and there was no evidence of heterogeneity among cohorts. When we considered diabetes and hypertension in the adjustment, the effect estimates for $\mathrm{PM}_{10}$ and for $\mathrm{PM}_{2.5}$ were slightly lower (hazard ratio 1.11 (95\% confidence interval 1.00 to 1.24 ) and 1.11 (0.96 to 1.28 ), respectively). When we considered physical activity, alcohol consumption, and BMI in the eight cohorts with available information, the association between particulate matter and incidence of coronary events remained stable. Adjustment for cholesterol in the four cohorts with this variable did not alter the results. Adjustment for location of residence (urban, suburban/rural) slightly increased the effect estimates. In 63 121 participants who did not change their address during the follow-up, the effect estimate of air pollution was higher than in the whole population (hazard ratio 1.16 (1.01 to 1.32) for 10 $\mu \mathrm{g} / \mathrm{m}^{3} \mathrm{PM}_{10}$, and 1.18 (0.98 to 1.42) for $5 \mu \mathrm{g} / \mathrm{m}^{3} \mathrm{PM}_{2.5}$ ), possibly because of more accurate exposure assignment. Exclusion of the large DCH study did not influence the results. When we restricted the meta-analysis to nine cohorts with exposure models with high cross validation $\left(\mathrm{R}^{2}>60\right)$ for $\mathrm{PM}_{10}$ and six cohorts for $\mathrm{PM}_{2.5}$, we found stronger associations (hazard ratio 1.18 (1.05 to 1.33 ) for $10 \mu \mathrm{g} / \mathrm{m}^{3} \mathrm{PM}_{10}$, and 1.35 (1.04 to 1.74 ) for $5 \mu \mathrm{g} / \mathrm{m}^{3}$ $\left.\mathrm{PM}_{2.5}\right)$. When we took individual and area level covariates into account, we found no evidence of clustering in the neighbourhoods (data not shown).

Effect modification by age showed stronger $\mathrm{PM}_{2.5}$ effects for those aged $60-74$ (hazard ratio $1.25,95 \%$ confidence interval 1.03 to 1.51$)$ and for those $>75(1.18,0.85$ to 1.64$)$ than among those aged under 60 ( $0.91,0.71$ to 1.15$)$, with $\mathrm{P}=0.11$ for effect modification. For all other effect modifiers, the $\mathrm{P}$ value of effect modification was far from significant $(\geq 0.22)$.

Table $7 \Downarrow$ shows the results of the threshold analysis for $\mathrm{PM}_{25}$ and $\mathrm{PM}_{10}$. When we restricted the analysis to participants from nine cohorts exposed to $\mathrm{PM}_{2.5}$ concentrations below the current European limit value $\left(<25 \mu \mathrm{g} / \mathrm{m}^{3}\right)$, there was a $18 \%$ increased risk per $5 \mu \mathrm{g} / \mathrm{m}^{3}$ increase in $\mathrm{PM}_{2.5}$ (hazard ratio $1.18,95 \%$ confidence interval 1.01 to 1.39). Similarly, for $\mathrm{PM}_{10}$ below the current European limit value $\left(40 \mu \mathrm{g} / \mathrm{m}^{3}\right)$ there was a $12 \%$ increased risk per $10 \mu \mathrm{g} / \mathrm{m}^{3}$ increase in $\mathrm{PM}_{10}(1.12,1.00$ to 1.27). The effect was present even at exposure levels $<15 \mu \mathrm{g} / \mathrm{m}^{3}$ for $\mathrm{PM}_{2.5}$ and $<20 \mu \mathrm{g} / \mathrm{m}^{3}$ for $\mathrm{PM}_{10}$. This result was not an artefact caused by cohort selection at different thresholds as it persisted when we the restricted analysis to the seven cohorts with data available in each threshold (table 7 , right columns $\Downarrow$ ).

\section{Discussion}

This European multicentre study found that long term exposure to particulate air pollution is associated with an increased risk of first coronary events. For both particulate matter with diameter $<10 \mu \mathrm{m}$ and $<2.5 \mu \mathrm{m}\left(\mathrm{PM}_{10}\right.$ and $\left.\mathrm{PM}_{2.5}\right)$, we found associations at levels below the current European limits. The results were substantially robust to adjustment for confounding and model specification.

\section{Comparison with other studies}

Our effect estimates are similar to or higher than those from two cohort studies from the US. For an increase of $10 \mu \mathrm{g} / \mathrm{m}^{3}$ in $\mathrm{PM}_{2.5}$, Miller and colleagues found a $21 \%$ (hazard ratio 1.21, $95 \%$ confidence interval 1.04 to 1.42 ) increased risk of first coronary heart disease in postmenopausal women, and a (non-significant) $6 \%$ higher risk of myocardial infarction. ${ }^{9}$ In the US Nurses' Health Study, ${ }^{11}$ there was an increased incidence of coronary heart disease for a $10 \mu \mathrm{g} / \mathrm{m}^{3}$ increase in $\mathrm{PM}_{2.5}$ (hazard ratio $1.11,0.79$ to 1.55 ) and for a $10 \mu \mathrm{g} / \mathrm{m}^{3}$ increase in coarse particles $(1.04,0.82$ to 1.32$)$. In the UK, Atkinson and colleagues found a non-significant $1 \%(-2 \%$ to $5 \%)$ higher risk in incident myocardial infarction per $3 \mu \mathrm{g} / \mathrm{m}^{3}$ increase in $\mathrm{PM}_{10}{ }^{14}$ In the California Teachers Study, Lipsett and colleagues found no evidence of increased myocardial infarction incidence per 
$10 \mu \mathrm{g} / \mathrm{m}^{3}$ increments in $\mathrm{PM}_{2.5}$ and $\mathrm{PM}_{10}{ }^{12}$ The results are also in line with the evidence produced so far by studies on the short term effects of particulate matter on ischaemic heart disease..$^{35} 36$ We found a suggestion of a higher risk associated with particulate exposure in participants aged over 60 . Evidence on which age range is the most susceptible is mixed. Miller and colleagues found a higher risk in those aged $>70$ compared with $<70,{ }^{9}$ while Gan and colleagues found higher risks in first admissions to hospital for coronary heart disease in both those aged $<60$ and 60-69 than those aged $\geq 70$. $^{5}$

We found an effect of $\mathrm{PM}_{25}$ below 25, 20, and $15 \mu \mathrm{g} / \mathrm{m}^{3}$, and our results highlight the possible harmful health effects of fine particles well below the current EU annual limit for $\mathrm{PM}_{2.5}$. It is clear that generalisability of these findings to the entire European population is not straightforward because the cohorts are not representative of the European population. Besides the differences among the cohorts in age range and underlying risk profiles, however, we detected no heterogeneity in the effect estimates among the cohorts.

There are several possible mechanisms through which exposure to air pollution can affect the cardiovascular system, including systemic inflammation, systemic oxidative stress, thrombosis and coagulation, changes in blood pressure, progression of atherosclerosis, and reduced heart rate variability. ${ }^{15}$ Most of this evidence comes from studies of short term exposures and short term responses of cardiovascular function. The pathways implicated provide plausible biological mechanisms based on repeated exacerbations of cardiovascular risk factors potentially leading to long term progression of coronary artery disease..$^{15} 37$

It is unlikely that our findings are driven by an excess in coronary disease mortality because in these and some other cohorts participating in the ESCAPE project we could not find much evidence of an association between exposure to air pollution and mortality for ischaemic heart disease or myocardial infarction. ${ }^{38}$

Our main positive results for coronary events are for an association with particulate matter, and the evidence for other pollutants such as nitrogen oxides could be considered as suggestive based on the small positive estimates. Several predictor variables explained the spatial variation of $\mathrm{PM}_{10}$ and $\mathrm{PM}_{2.5}$ in ESCAPE study areas,${ }^{30}$ including not only traffic variables but also population density, industrial sources, urban green, and altitude. Estimated $\mathrm{PM}_{10}$ at place of residence therefore represents not only traffic emissions. In contrast, the spatial variation in $\mathrm{PM}_{2.5}$ absorbance was more exclusively explained by traffic variables. Our findings suggest that sources other than vehicular traffic can have an important role on the risk of acute ischaemic heart disease.

\section{Strengths and weaknesses}

In this first multicentre European study to investigate long term effects of air pollution on incidence of coronary events, we used a standardised approach for assessment of exposure with respect to measurements and modelling. ${ }^{28-31}$ Both the measurements and the land use regression models were centrally validated, and data analyses were centrally planned and conducted in the same way in each cohort. The European locations captured in this project provide a wide range of exposures and mixtures that vary from north to south. Although the design of the study did not allow us to benefit from the large variability of pollutant exposure between cohorts, we took advantage of the exposure variation within cohorts. The use of existing cohorts, not designed for air pollution epidemiology, might be seen as a limitation of the ESCAPE project. Indeed, we were able to perform a planned meta-analysis and make the most of existing studies in an efficient way. Therefore, we consider these data the first systematic assessment of the impact of ambient particles on incident coronary artery disease in Europe, highlighting that the burden of disease might be underestimated when estimates of mortality are considered alone..$^{15} 39$

The assessment of exposure was conducted in 2008-11, while the cohorts were enrolled over 15 years, starting in 1992. The use of modelled concentrations based on measurements taken long after the beginning of the study assumes that spatial contrasts were stable over time, an assumption that has been supported from observations in different settings. ${ }^{40-42}$ In the ESCAPE project considerable effort was made to take this problem into account; when possible, we back-extrapolated air pollution concentrations. ${ }^{17}$ Analyses of the association between back-extrapolated concentrations and incidence of coronary events made no important difference.

We collected individual data on many cardiovascular risk factors to deal with confounding. When we compared the results of the "base model" with a model containing additional cardiovascular risk factors, we obtained similar results. It should be noted that variables used to adjust for area level socioeconomic status were different from cohort to cohort, ranging from the percentage of low income inhabitants in a $5 \mathrm{~km}$ grid in KORA to a census block deprivation index in the Italian cohorts. We could not determine whether this might have affected the results, but general adjustment for area level socioeconomic indicators did not have much influence in cohort specific analyses. Data on the most relevant cardiovascular risk factors (smoking, diabetes or hypertension, BMI, physical activity) were available for almost all cohorts, therefore a strong bias in the effect estimates caused by confounding is unlikely. Nevertheless, we cannot rule out residual confounding by, for example, differences in diet. In addition, we observed evidence for effect modification, but even within this large multicentre study, the power to reliably detect effect modification is limited and therefore we selected a limited set of interactions to evaluate a priori.

All cohorts, with the exception of the DCH study, enrolled fewer than 10000 participants, making the statistical power to detect effects of air pollution in single studies limited. The

characteristics of participants were heterogeneous, with two cohorts having younger participants than the others. Younger age could be a reason for the smaller effects found in some of the cohorts. Finally, in nine out of 11 cohorts outcomes were ascertained from routine administrative databases, which could have led to a less precise effect estimate from misclassification of the outcome.

When we included only the studies with the best exposure assessment models (performance of the land use regression leave-one-out cross validation $\mathrm{R}^{2}>60 \%$ ), we found increased effect estimates. This could be because of reduced misclassification of exposure. The cohorts with validation $\mathrm{R}^{2}$ $\leq 60 \%$, however, had young participants and (in particular the Italian ones) had higher rates of smoking and a better exposure assessment might be not the only explanation.

\section{Conclusions}

Our study suggests an association between long term exposure to inhalable particulate matter and incidence of coronary events. These associations remained for exposure concentrations below the current European limits. The results of this study, together with other ESCAPE findings, support lowering of European limits for particulate air pollution to adequately protect public health. 


\section{What is already known on this topic}

Ambient particulate matter air pollution is estimated to cause 3.1 million deaths worldwide per year, and $22 \%$ of DALYs (disability adjusted life years) from ischaemic heart disease

The association between long term exposure to air pollution and incidence of coronary events remains controversial

\section{What this study adds}

There is an association between outdoor particulate matter and incidence of acute coronary events, even for exposure levels below the current European limits

The burden of disease attributable to outdoor particulate matter might be underestimated if only estimates of mortality are considered The results of this study support lowering of the EU limits for particulate matter air pollution

We thank Marjan Tewis, Marieke Oldenwening, Marloes Eeftens, Ulrich Quass, Lee-Jane Sally Liu for their help with exposure assessment and data management within ESCAPE.

For the Finnish part, additional funding came from the Academy of Finland (project number 129317). Exposure assessment was performed by Tarja Yli-Tuomi, Pekka Taimisto, and Arto Pennanen from the Department of Environmental Health. Mortality, area-level SES, and building data were provided by Statistics Finland.

The four Swedish cohorts (SNAC-K, SALT, 60y, SDPP) were partially funded by the Swedish Environmental Protection Agency, the Swedish Council for Working Life and Social Research and the Swedish Heart-Lung Foundation. The SALT cohort was additionally supported by NIH grant AG-08724. The 60 year cohort was additionally funded by the Stockholm County Council and the Swedish Research Council (longitudinal research and 0593). The SDPP cohort was additionally funded by the Stockholm County Council; the Swedish Research Council; the Swedish Diabetes Association; and the Novo Nordisk Scandinavia. We thank the Heinz Nixdorf Foundation, the German Ministry of Education and Science (BMBF), the German Aerospace Center (Deutsches Zentrum für Luft- und Raumfahrt (DLR)), and the German Research Foundation (DFG HO 3314/2-1 and JO170/8-1), Bonn, Germany, for their generous support of Heinz Nixdorf Recall study. The KORA research platform and the MONICA Augsburg studies were initiated and financed by the Helmholtz Zentrum München, German Research Center for Environmental Health, which is funded by the German Federal Ministry of Education and Research and by the State of Bavaria. The SIDRIA cohort study was partially funded by the Italian Ministry of Health. Giuseppe Costa provided data from the Turin Longitudinal Study for the follow-up of the SIDRIA-Turin cohort. Exposure assessment in Turin was performed by Daniela Raffaele and Marco Gilardetti. Noise assessment in Turin was performed by Daniele Grasso and Jacopo Fogola (Regional Agency for the Protection of the Environment of Piedmont). We thank Simone Bucci, Patrizio Pasquinelli, and Eleonora Zirro for exposure assessment in Rome.

Contributors: GC contributed to the design, exposure assessment, data analyses, and drafted the manuscript; FF contributed to the design, provided local cohort data and drafted the manuscript; MS contributed to the design, statistical script, and data analyses; ZJA, RH contributed to the statistical script and data analysis; $\mathrm{CB}, \mathrm{FH}, \mathrm{EM}, \mathrm{JPen}, \mathrm{APy}, \mathrm{FR}$, and AT contributed to the data analyses; $\mathrm{RB}, \mathrm{GH}$ contributed to the design, exposure assessment and statistical script; BC, UdF, RE, LF, $\mathrm{MH}, \mathrm{AH}, \mathrm{KHJ}, \mathrm{KL}, \mathrm{PKEM}, \mathrm{CGO}, \mathrm{KO}$, NLP, JPek, CS, and VS provided local cohort data; $C G$ contributed to exposure assessment and provided local cohort data; BH, ORN, GP, and PV contributed to the design and provided local cohort data; MK contributed to the exposure assessment and the data analyses; KTE, DH, TL, AR, WS, and KdH contributed to exposure assessment; GW and KW contributed to the statistical script; $\mathrm{BB}$ and $\mathrm{APe}$ contributed to the design and drafted the manuscript. All authors contributed to critical reading of and comments to the manuscript, interpretation of data and approved the final draft. GC is guarantor.

Funding: The research leading to these results has received funding from the European Community's Seventh Framework Program
(FP7/2007-2011) under grant agreement No 211250. The sources of funding had no role in study design, data collection, analyses, interpretation, and decision to submit the article for publication.

Competing interests: All authors have completed the ICMJE uniform disclosure form at www.icmje.org/coi_disclosure.pdf and declare: no support from any organisation for the submitted work; no financial relationships with any organisations that might have an interest in the submitted work in the previous three years; no other relationships or activities that could appear to have influenced the submitted work.

Ethical approval: The original cohort studies were approved by appropriate institutional review boards complying with all relevant national, state, and local regulations.

Transparency statement: The lead author affirms that this manuscript is an honest, accurate, and transparent account of the study being reported; that no important aspects of the study have been omitted; and that any discrepancies from the study as planned have been explained. Data sharing: meta-analytic data and statistical code are available from the corresponding author.

1 Lim SS, Vos T, Flaxman AD, Danei G, Shibuya K, Adair-Rohani H, et al. A comparative risk assessment of burden of disease and injury attributable to 67 risk factor clusters in 21 regions, 1990-2010: a systematic analysis for the Global Burden of Disease Study 2010. Lancet 2012;380:2224-60.

2 Beelen R, Hoek G, van den Brandt PA, Goldbohm RA, Fischer P, Schouten LJ, et al. Long-term effects of traffic-related air pollution on mortality in a Dutch cohort (NLCS-AIR study). Environ Health Perspect 2008;116:196-202.

3 Chen LH, Knutsen SF, Shavlik D, Beeson WL, Petersen F, Ghamsary M, et al. The association between fatal coronary heart disease and ambient particulate air pollution: Are females at greater risk? Environ Health Perspect 2005;113:1723-9.

4 Crouse DL, Peters PA, van Donkelaar A, Goldberg MS, Villeneuve PJ, Brion O, et al. Risk of nonaccidental and cardiovascular mortality in relation to long-term exposure to low concentrations of fine particulate matter: a Canadian national-level cohort study. Environ Health Perspect 2012;120:708-14.

5 Gan WQ, Koehoorn M, Davies HW, Demers PA, Tamburic L, Brauer M. Long-term exposure to traffic-related air pollution and the risk of coronary heart disease hospitalization and mortality. Environ Health Perspect 2011;119:501-7.

6 Jerrett M, Burnett RT, Ma R, Pope CA 3rd, Krewski D, Newbold KB, et al. Spatial analysis of air pollution and mortality in Los Angeles. Epidemiology 2005:16:727-36.

7 Krewski D, Jerrett M, Burnett RT, Ma R, Hughes E, Shi Y, et al. Extended follow-up and spatial analysis of the American Cancer Society study linking particulate air pollution and mortality. HEI Research Report 140. Health Effects Institute, 2009.

8 Laden F, Schwartz J, Speizer FE, Dockery DW. Reduction in fine particulate air pollution and mortality: extended follow-up of the Harvard Six Cities study. Am J Respir Crit Care Med 2006;173:667-72.

9 Miller KA, Siscovick DS, Sheppard L, Shepherd K, Sullivan JH, Anderson GL, et al. Long-term exposure to air pollution and incidence of cardiovascular events in women. $N$ Engl J Med 2007;356:447-58.

10 Pope CA 3rd, Burnett RT, Thurston GD, Thun MJ, Calle EE, Krewski D, et al. Cardiovascular mortality and long-term exposure to particulate air pollution: epidemiological evidence of general pathophysiological pathways of disease. Circulation 2004:109:71-7.

11 Puett RC, Hart JE, Yanosky JD, Paciorek C, Schwartz J, Suh H, et al. Chronic fine and coarse particulate exposure, mortality, and coronary heart disease in the Nurses' Health Study. Environ Health Perspect 2009;117:1697-701.

12 Lipsett MJ, Ostro BD, Reynolds P, Goldberg D, Hertz A, Jerrett M, et al. Long-term exposure to air pollution and cardiorespiratory disease in the California teachers study cohort. Am J Respir Crit Care Med 2011:184:828-35.

13 Raaschou-Nielsen O, Andersen ZJ, Jensen SS, Ketzel M, Sørensen M, Hansen J, et al. Traffic air pollution and mortality from cardiovascular disease and all causes: a Danish cohort study. Environ Health 2012;11:60.

14 Atkinson RW, Carey IM, Kent AJ, van Staa TP, Anderson HR, Cook DG. Long-term exposure to outdoor air pollution and incidence of cardiovascular diseases. Epidemiology 2013;24:44-53.

15 Brook RD, Rajagopalan S, Pope CA 3rd, Brook JR, Bhatnagar A, Diez-Roux AV, et al; American Heart Association Council on Epidemiology and Prevention, Council on the Kidney in Cardiovascular Disease, and Council on Nutrition, Physical Activity and Metabolism. Particulate matter air pollution and cardiovascular disease: an update to the scientific statement from the American Heart Association. Circulation 2010;121:2331-78.

16 ESCAPE. European study of cohorts for air pollution effects. www.escapeproject.eu. 
17 Beelen R, Raaschou-Nielsen O, Stafoggia M, Andersen ZJ, Weinmayr G, Hoffmann B, et al. Effects of long-term exposure to air pollution on natural cause mortality: an analysis of 22 European cohorts within the multi-center ESCAPE project. Lancet Early online publication 9 December 2013. http://dx.doi.org/10.1016/S0140-6736(13)62158-3.

18 Vartiainen E, Laatikainen T, Peltonen M, Juolevi A, Männistö S, Sundvall J, et al. Thirty-five-year trends in cardiovascular risk factors in Finland. Int $J$ Epidemio 2010;39:504-18.

19 Meinow B, Kåreholt I, Lagergren M. According to need? Predicting the amount of municipa home help allocated to elderly recipients in an urban area of Sweden. Health Soc Care Community 2005;13:366-377.

20 Lichtenstein P, Sullivan PF, Cnattingius S, Gatz M, Johansson S, Carlström E, et al. The Swedish Twin Registry in the Third Millennium—an update. Twin Res Hum Genet 2006;9:875-82.

21 Wandell PE, Wajngot A, de Faire U, Hellenius ML. Increased prevalence of diabetes among immigrants from non-European countries in 60-year-old men and women in Sweden. Diabet Metab 2007;33:30-6.

22 Eriksson AK, Ekbom A, Granath F, Hilding A, Efendic S, Ostenson CG. Psychological distress and risk of pre-diabetes and Type 2 diabetes in a prospective study of Swedish middle-aged men and women. Diabet Med 2008;25:834-42.

23 Tiønneland A, Olsen A, Boll K, Stripp C, Christensen J, Engholm G, et al. Study design, exposure variables, and socioeconomic determinants of participation in diet, cancer and health: a population-based prospective cohort study of 57,053 men and women in Denmark. Scand J Public Health 2007;35:432-41.

24 Erbel R, Möhlenkamp S, Moebus S, Schmermund A, Lehmann N, Stang A, et al. Heinz Nixdorf Recall Study Investigative Group. Coronary risk stratification, discrimination, and reclassification improvement based on quantification of subclinical coronary atherosclerosis: the Heinz Nixdorf Recall study. J Am Coll Cardiol 2010;56:1397-406.

25 Holle R, Happich M, Löwel H, Wichmann HE; MONICA/KORA Study Group. KORA-a research platform for population based health research. Gesundheitswesen 2005;67(supp 1):S19-25.

26 Cesaroni G, Badaloni C, Porta D, Forastiere F, Perucci CA. Comparison between various indices of exposure to traffic-related air pollution and their impact on respiratory health in adults. Occup Environ Med 2008:65:683-90.

27 Vineis P, Hoek G, Krzyzanowski M, Vigna-Taglianti F, Veglia F, Airoldi L, et al. Air pollution and risk of lung cancer in a prospective study in Europe. Int $J$ Cancer 2006;119:169-74.

28 Cyrys J, Eeftens M, Heinrich J, Ampe C, Armengaud A, Beelen R, et al. Variation of $\mathrm{NO}_{2}$ and $\mathrm{NO}_{x}$ concentrations between and within 36 European study areas: results from the ESCAPE study. Atmosph Environ 2012;62:374-90.

29 Eeftens M, Tsai M, Ampe C, Anwander B, Beelen R, Bellander T, et al Spatial variation of $\mathrm{PM}_{2.5}, \mathrm{PM}_{10}, \mathrm{PM}_{2.5}$ absorbance and PMcoarse concentrations between and within 20 European study areas and the relationship with $\mathrm{NO}_{2}$-results of the ESCAPE project. Atmosph Environ 2012;62:303-17.

30 Eeftens M, Beelen R, de Hoogh K, Bellander T, Cesaroni G, Cirach M, et al. Development of land use regression models for $\mathrm{PM}(2.5), \mathrm{PM}(2.5)$ absorbance, $\mathrm{PM}(10)$ and $\mathrm{PM}$ (coarse) in 20 European Study Areas; Results of the ESCAPE Project. Environ Sci Technol 2012;46:11195-205

31 Beelen R, Hoek G, Vienneau D, Eeftens M, Dimakopoulou K, Pedeli X, et al. Development of $\mathrm{NO}_{2}$ and $\mathrm{NO}_{x}$ land use regression models for estimating air pollution exposure in 36 study areas in Europe-the ESCAPE project. Atmosph Environ doi:10.1016/.atmosenv. 2013.02.037.

32 Diez Roux AV, Merkin SS, Hannan P, Jacobs DR, Kiefe Cl. Area characteristics, individual-level socioeconomic indicators, and smoking in young adults: the coronary artery disease risk development in young adults study. Am J Epidemiol 2003;157:315-26.

33 DerSimonian R, Laird N. Meta-analysis in clinical trials. Control Clin Trials 1986;7:177-88.

34 Higgins JP, Thompson SG. Quantifying heterogeneity in a meta-analysis. Stat Med 2002;21:1539-58.

35 Zanobetti A, Schwartz J. The effect of particulate air pollution on emergency admissions for myocardial infarction: a multicity case-crossover analysis. Environ Health Perspect 2005;113:978-82.

36 Pope CA III, Muhlestein JB, May HT, Renlund DG, Anderson JL, Horne BD. Ischemic heart disease events triggered by short-term exposure to fine particulate air pollution. Circulation 2006;114:2443-8.

37 Peters A. Ambient particulate matter and the risk for cardiovascular disease. Prog Cardiovasc Dis 2011:53:327-33.

38 Beelen R, Stafoggia M, Raaschou-Nielsen M, Andersen ZJ, Xun WW, Katsouyanni K, et al. Long-term exposure to air pollution and cardiovascular mortality: an analysis of 22 European cohorts within the ESCAPE project. Epidemiology (in press).

39 Hoek G, Krishnan RM, Beelen R, Peters A, Ostro B, Brunekreef B, et al. Long-term air pollution exposure and cardio- respiratory mortality: a review. Environ Health 2013;12:43.

40 Cesaroni G, Porta D, Badaloni C, Stafoggia M, Eeftens M, Meliefste K, et al. Nitrogen dioxide levels estimated from land use regression models several years apart and association with mortality in a large cohort study. Environ Health 2012;11:48.

41 Eeftens M, Beelen R, Fischer P, Brunekreef B, Meliefste K, Hoek G. Stability of measured and modelled spatial contrasts in $\mathrm{NO}_{2}$ over time. Occup Environ Med 2011;68:765-70.

42 Wang R, Henderson SB, Sbihi $\mathrm{H}$, Allen RW, Brauer M. Temporal stability of land use regression models for traffic-related air pollution. Atmosph Environ 2013;64:312-9.

Accepted: 04 December 2013

\section{Cite this as: BMJ 2014;348:f7412}

This is an Open Access article distributed in accordance with the Creative Commons Attribution Non Commercial (CC BY-NC 3.0) license, which permits others to distribute, remix, adapt, build upon this work non-commercially, and license their derivative works on different terms, provided the original work is properly cited and the use is non-commercial. See: http://creativecommons.org/licenses/by-nc/3.0/. 


\section{Tables}

Table 1/ Summary description of 11 European cohorts from five countries contributing data to study long term exposure to ambient air pollution and incidence of acute coronary events

\begin{tabular}{|c|c|c|c|c|c|c|c|c|c|c|c|}
\hline \multirow[b]{2}{*}{ Variable } & \multirow[b]{2}{*}{ FINRISK } & \multirow[b]{2}{*}{ SNAC-K } & \multirow[b]{2}{*}{ SALT } & \multirow{2}{*}{$\begin{array}{l}60 \text { year } \\
\text { olds }\end{array}$} & \multirow[b]{2}{*}{ SDPP } & \multirow[b]{2}{*}{$\mathrm{DCH}$} & \multirow[b]{2}{*}{ HNR } & \multirow[b]{2}{*}{ KORA } & \multirow{2}{*}{$\begin{array}{l}\text { EPIC } \\
\text { Turin }\end{array}$} & \multicolumn{2}{|c|}{ SIDRIA } \\
\hline & & & & & & & & & & Turin & Rome \\
\hline $\begin{array}{l}\text { No of } \\
\text { participants }\end{array}$ & 9995 & 2684 & 6084 & 3686 & 7723 & 35693 & 4433 & 8301 & 7230 & 5137 & 9200 \\
\hline $\begin{array}{l}\text { Person years at } \\
\text { risk }\end{array}$ & 105060 & 16256 & 51756 & 39978 & 106995 & 464055 & 34941 & 84595 & 91490 & 56366 & 102894 \\
\hline $\begin{array}{l}\% \text { of original } \\
\text { cohort }\end{array}$ & 93.5 & 89.4 & 92.3 & 91.0 & 97.6 & 96.0 & 99.3 & 94.0 & 82.4 & 95.5 & 87.1 \\
\hline No of cases & 212 & 200 & 204 & 165 & 181 & 3293 & 135 & 282 & 157 & 123 & 205 \\
\hline Study location & $\begin{array}{c}\text { Turku and } \\
\text { Helsinki } \\
\text { (Finland) }\end{array}$ & $\begin{array}{l}\text { Stockholm } \\
\text { (Sweden) }\end{array}$ & $\begin{array}{l}\text { Stockholm } \\
\text { (Sweden) }\end{array}$ & $\begin{array}{l}\text { Stockholm } \\
\text { (Sweden) }\end{array}$ & $\begin{array}{l}\text { Stockholm } \\
\text { (Sweden) }\end{array}$ & $\begin{array}{c}\text { Copenhagen } \\
\text { (Denmark) }\end{array}$ & $\begin{array}{l}\text { Ruhr Area } \\
\text { (Germany) }\end{array}$ & $\begin{array}{l}\text { Augsburg } \\
\text { (Germany) }\end{array}$ & $\begin{array}{l}\text { Turin } \\
\text { (Italy) }\end{array}$ & Turin (Italy) & $\begin{array}{l}\text { Rome } \\
\text { (Italy) }\end{array}$ \\
\hline $\begin{array}{l}\text { Years of } \\
\text { enrolment }\end{array}$ & $\begin{array}{l}\text { 1992, } 1997 \\
2002,2007\end{array}$ & 2001-04 & $1998-2002$ & 1997-99 & $1992-98$ & 1993-97 & $2000-03$ & $\begin{array}{c}\text { 1994-95, } \\
\text { 1999-2001 }\end{array}$ & 1993-98 & 1999 & 1999 \\
\hline
\end{tabular}


Table 2| Individual baseline characteristics from 11 European cohorts from five countries contributing data to study long term exposure to ambient air pollution and incidence of acute coronary events. Values are numbers (percentages) unless stated otherwise

\begin{tabular}{|c|c|c|c|c|c|c|c|c|c|c|c|}
\hline \multirow[b]{2}{*}{ Variable } & \multirow[b]{2}{*}{ FINRISK } & \multirow[b]{2}{*}{ SNAC-K } & \multirow[b]{2}{*}{ SALT } & \multirow{2}{*}{$\begin{array}{l}60 \text { year } \\
\text { olds }\end{array}$} & \multirow[b]{2}{*}{ SDPP } & \multirow[b]{2}{*}{ DCH } & \multirow[b]{2}{*}{ HNR } & \multirow[b]{2}{*}{ KORA } & \multirow{2}{*}{$\begin{array}{l}\text { EPIC } \\
\text { Turin }\end{array}$} & \multicolumn{2}{|c|}{ SIDRIA } \\
\hline & & & & & & & & & & Turin & Rome \\
\hline No of participants & 9995 (100) & $2684(100)$ & $6084(100)$ & $3686(100)$ & $7723(100)$ & $35693(100)$ & $4433(100)$ & $8301(100)$ & $7230(100)$ & $5137(100)$ & $9200(100)$ \\
\hline $\begin{array}{l}\text { Mean }(S D) \text { age } \\
\text { (years) }\end{array}$ & $48(13)$ & $74(11)$ & $59(11)$ & $60(0)$ & $47(5)$ & $57(4)$ & $59(8)$ & $49(14)$ & $50(8)$ & $44(6)$ & $44(6)$ \\
\hline Women & $5460(55)$ & $1751(65)$ & $3557(58)$ & $1967(53)$ & $4721(61)$ & $19302(54)$ & $2309(52)$ & $4275(51)$ & $3472(48)$ & $2677(52)$ & $4859(53)$ \\
\hline \multicolumn{12}{|l|}{ Marital status: } \\
\hline Single & $1601(16)$ & $397(15)$ & $835(14)$ & $170(5)$ & $1272(16)^{*}$ & $2352(7)$ & $256(6)$ & $879(11)$ & $438(6)$ & $121(2)$ & $0(0)$ \\
\hline $\begin{array}{l}\text { Married/living with } \\
\text { partner }\end{array}$ & $7009(70)$ & $1263(47)$ & $4103(67)$ & $2628(71)$ & $6451(84)$ & $24673(69)$ & $3319(75)$ & $6292(76)$ & $6183(86)$ & $4897(95)$ & $9200(100)$ \\
\hline Divorced/separated & $1051(11)$ & $362(13)$ & $678(11)$ & $630(17)$ & - & $6599(18)$ & $444(10)$ & $620(7)$ & $375(5)$ & $37(1)$ & $0(0)$ \\
\hline Widowed & $334(3)$ & $662(25)$ & $468(8)$ & $258(7)$ & - & $2069(6)$ & $414(9)$ & $510(6)$ & $234(3)$ & $82(2)$ & $0(0)$ \\
\hline \multicolumn{12}{|l|}{ Education: } \\
\hline $\begin{array}{l}\text { Primary school or } \\
\text { less }\end{array}$ & $3029(30)$ & $705(26)$ & $1332(22)$ & $1030(28)$ & $1996(26)$ & $10589(30)$ & $499(11)$ & $1024(12)$ & $3168(44)$ & $898(17) \dagger$ & $4130(45)$ \\
\hline Secondary school & $5217(52)$ & $1128(42)$ & $2606(43)$ & $1631(44)$ & $3453(45)$ & $16943(47)$ & $2466(56)$ & $6200(65)$ & $3081(43)$ & $3668(71)$ & $3690(40)$ \\
\hline $\begin{array}{l}\text { University degree } \\
\text { and more }\end{array}$ & $1749(17)$ & $851(32)$ & $2146(35)$ & $1025(28)$ & $2274(29)$ & $8161(23)$ & $1468(33)$ & $1077(13)$ & $981(14)$ & $571(11)$ & $1380(15)$ \\
\hline \multicolumn{12}{|l|}{ Occupational status: } \\
\hline $\begin{array}{l}\text { Employed/self } \\
\text { employed }\end{array}$ & $7092(71)$ & $2016(75)$ & - & $1881(51)$ & $7088(92)$ & $28600(80)$ & $1859(42)$ & $4908(59)$ & - & 3727 (73) & $6500(71)$ \\
\hline Unemployed & $610(6)$ & $668(25) \ddagger$ & - & $374(10)$ & $635(8) \ddagger$ & $7093(20) \ddagger$ & $630(14)$ & $272(3)$ & - & $349(7)$ & $393(4)$ \\
\hline $\begin{array}{l}\text { Homemaker or } \\
\text { housewife }\end{array}$ & $351(4)$ & - & - & $290(8)$ & - & - & $1664(38)$ & $1188(14)$ & - & $1061(21)$ & $2307(25)$ \\
\hline Retired & $1942(19)$ & - & 一 & $1141(31)$ & - & - & $280(6)$ & $1933(23)$ & - & $0(0)$ & $0(0)$ \\
\hline \multicolumn{12}{|l|}{ Smoking status: } \\
\hline Current smoker & $2603(26)$ & $394(15)$ & $1224(20)$ & $751(20)$ & $2022(26)$ & $12793(36)$ & $1040(23)$ & $2162(26)$ & $1768(24)$ & $2117(41)$ & $3884(42)$ \\
\hline Former smoker & $2808(28)$ & $927(34)$ & $2678(44)$ & $1429(39)$ & $2815(36)$ & $9944(28)$ & $1482(33)$ & $2517(30)$ & $2368(33)$ & $1085(21)$ & $2147(23)$ \\
\hline Never smoker & $4584(46)$ & $1363(51)$ & $2182(36)$ & $1506(41)$ & $2886(37)$ & $12956(36)$ & $1911(43)$ & $3622(44)$ & 3094 (43) & $1935(38)$ & 3169 (34) \\
\hline $\begin{array}{l}\text { Mean (SD) years of } \\
\text { smoking among ever } \\
\text { smokers }\end{array}$ & $15(12)$ & $30(17)$ & - & $26(13)$ & $20(10)$ & $29(10)$ & $36(9) \S$ & $21(13)$ & $23(10)$ & $18(8)$ & $18(7)$ \\
\hline $\begin{array}{l}\text { Mean (SD) No of } \\
\text { cigarettes/day } \\
\text { among current } \\
\text { smokers }\end{array}$ & $15(9)$ & $11(8)$ & $13(8)$ & $13(7)$ & $14(7)$ & $17(10)$ & $17(12)$ & $15(11)$ & $14(9)$ & $15(9)$ & $15(9)$ \\
\hline
\end{tabular}

${ }^{*}$ All except married/living with partner.

$\dagger<6$ years of schooling.

$\ddagger$ All except employed.

§Only among current smokers. 
Table 3| Air pollution exposure at residential address of individuals from 11 European cohorts from five countries contributing data to study long term exposure to ambient air pollution and incidence of acute coronary events. Figures are means and 5-95th centile ranges, correlation coefficients between PM2.5 and other pollutants, and $\mathrm{R}^{2}$ of models and their cross validation

\begin{tabular}{|c|c|c|c|c|c|c|c|c|c|c|c|}
\hline \multirow[b]{2}{*}{ Variable } & \multirow[b]{2}{*}{ FINRISK } & \multirow[b]{2}{*}{ SNAC-K } & \multirow[b]{2}{*}{ SALT } & \multirow{2}{*}{$\begin{array}{l}60 \text { year } \\
\text { olds }\end{array}$} & \multirow[b]{2}{*}{ SDPP } & \multirow[b]{2}{*}{ DCH } & \multirow[b]{2}{*}{ HNR } & \multirow[b]{2}{*}{ KORA } & \multirow{2}{*}{$\begin{array}{l}\text { EPIC } \\
\text { Turin }\end{array}$} & \multicolumn{2}{|c|}{ SIDRIA } \\
\hline & & & & & & & & & & Turin & Rome \\
\hline \multicolumn{12}{|c|}{ Mean (5th-95th centile) annual air pollution $\left(\mu \mathrm{g} / \mathrm{m}^{3}\right)$ at residence address } \\
\hline $\mathrm{PM}_{10}$ & $14(10-20)$ & $16(6-29)$ & $15(7-21)$ & $15(7-21)$ & $14(6-17)$ & $17(14-20)$ & $\begin{array}{c}28 \\
(25-32)\end{array}$ & $20(16-24)$ & $\begin{array}{c}46 \\
(39-52)\end{array}$ & $\begin{array}{c}48 \\
(41-54)\end{array}$ & $36(31-47)$ \\
\hline Coarse PM & $7(4-11)$ & $8(1-19)$ & $7(2-12)$ & $7(1-12)$ & $6(1-9)$ & $6(4-7)$ & $10(7-12)$ & $6(5-8)$ & $\begin{array}{c}16 \\
(12-20)\end{array}$ & $\begin{array}{c}17 \\
(13-20)\end{array}$ & $17(12-24)$ \\
\hline $\mathrm{PM}_{2.5}$ & $8(6-9)$ & $8(6-10)$ & $7(5-9)$ & $7(5-9)$ & $7(5-8)$ & $11(10-13)$ & $\begin{array}{c}18 \\
(17-20)\end{array}$ & $14(13-15)$ & $\begin{array}{c}30 \\
(27-33)\end{array}$ & $\begin{array}{c}31 \\
(29-34)\end{array}$ & $19(17-23)$ \\
\hline $\begin{array}{l}\text { Absorbance } \\
\mathrm{PM}_{2.5}, 10^{-5} / \mathrm{m}\end{array}$ & $\begin{array}{c}0.9 \\
(0.5-1.2) \\
\end{array}$ & $0.8(0.5-1.2)$ & $\begin{array}{c}0.6 \\
(0.4-0.9) \\
\end{array}$ & $\begin{array}{c}0.6 \\
(0.4-0.9) \\
\end{array}$ & $\begin{array}{c}0.5 \\
(0.4-0.7) \\
\end{array}$ & $1.2(0.8-1.5)$ & $\begin{array}{c}1.6 \\
(1.2-2.2) \\
\end{array}$ & $\begin{array}{c}1.7 \\
(1.5-2.0) \\
\end{array}$ & $\begin{array}{c}3.1 \\
(2.3-3.6) \\
\end{array}$ & $\begin{array}{c}3.2 \\
(2.6-3.8) \\
\end{array}$ & $2.7(2.2-4.0)$ \\
\hline $\mathrm{NO}_{2}$ & $15(9-24)$ & $17(9-25)$ & $11(7-20)$ & $11(6-20)$ & $8(6-11)$ & $16(8-30)$ & $\begin{array}{c}30 \\
(23-39)\end{array}$ & $19(14-26)$ & $\begin{array}{c}53 \\
(34-68) \\
\end{array}$ & $\begin{array}{c}60 \\
(42-77) \\
\end{array}$ & $39(26-56)$ \\
\hline $\mathrm{NO}_{x}$ & $24(14-41)$ & $33(15-58)$ & $19(12-40)$ & $19(12-39)$ & $14(12-20)$ & $27(7-66)$ & $\begin{array}{c}51 \\
(33-72) \\
\end{array}$ & $33(24-47)$ & $\begin{array}{c}96 \\
(62-132) \\
\end{array}$ & $\begin{array}{c}107 \\
(79-162)\end{array}$ & $82(39-122)$ \\
\hline $\begin{array}{l}\text { Daily No of } \\
\text { vehicles/day on } \\
\text { nearest road } \\
\end{array}$ & $\begin{array}{c}1670 \\
(50-9011)\end{array}$ & $\begin{array}{c}3726 \\
(500-21828)\end{array}$ & $\begin{array}{c}1454 \\
(500-6000)\end{array}$ & $\begin{array}{c}1455 \\
(500-6300)\end{array}$ & $\begin{array}{c}864 \\
(500-2575)\end{array}$ & $\begin{array}{c}2994 \\
(200-16145)\end{array}$ & - & $\begin{array}{c}1636 \\
(500-8367)\end{array}$ & $\begin{array}{c}3907 \\
(0-23951)\end{array}$ & $\begin{array}{c}4290 \\
(0-24379)\end{array}$ & $\begin{array}{c}2966 \\
(500-15312)\end{array}$ \\
\hline $\begin{array}{l}\text { Daily traffic load on } \\
\text { major roads in } 100 \mathrm{~m} \\
\text { buffer (thousand), } \\
\text { (vehicles } \times \text { meters/day) }\end{array}$ & $\begin{array}{c}633 \\
(0-3711) \\
\end{array}$ & $2307(0-6572)$ & $\begin{array}{c}578 \\
(0-3437)\end{array}$ & $\begin{array}{c}521 \\
(0-3048)\end{array}$ & $\begin{array}{c}109 \\
(0-986)\end{array}$ & $\begin{array}{c}1274 \\
(51-4719)\end{array}$ & $\begin{array}{c}1017 \\
(0-4302)\end{array}$ & $\begin{array}{c}444 \\
(0-2805)\end{array}$ & $\begin{array}{c}466 \\
(0-2340)\end{array}$ & $\begin{array}{c}804 \\
(0-4197)\end{array}$ & $\begin{array}{c}1417 \\
(0-6947)\end{array}$ \\
\hline \multicolumn{12}{|c|}{ Pearson correlations coefficients between $\mathrm{PM}_{2.5}$ and: } \\
\hline $\mathrm{PM}_{10}$ & 0.67 & 0.70 & 0.49 & 0.50 & 0.31 & 0.74 & 0.90 & 0.42 & 0.62 & 0.56 & 0.92 \\
\hline Coarse PM & 0.10 & 0.71 & 0.50 & 0.50 & 0.32 & 0.60 & 0.51 & 0.38 & 0.51 & 0.32 & 0.90 \\
\hline Absorbance $\mathrm{PM}_{2.5}$ & 0.98 & 0.98 & 0.84 & 0.84 & 0.90 & 0.49 & 0.76 & 0.50 & 0.77 & 0.73 & 0.78 \\
\hline $\mathrm{NO}_{2}$ & 0.41 & 0.82 & 0.60 & 0.61 & 0.61 & 0.57 & 0.63 & 0.45 & 0.72 & 0.67 & 0.69 \\
\hline \multicolumn{12}{|c|}{$\mathbf{R}^{2}$ of land use regression models and their leave one out cross validation } \\
\hline $\mathrm{PM}_{10}$ & $067-0.4$ & $0.82-0.77$ & $0.82-0.77$ & $0.82-0.77$ & $0.82-0.77$ & $0.75-0.64$ & $0.69-0.63$ & $0.83-0.75$ & $0.78-0.69$ & $0.78-0.69$ & $0.72-0.59$ \\
\hline Coarse PM & $0.61-0.3$ & $0.72-0.65$ & $0.72-0.65$ & $0.72-0.65$ & $0.72-0.65$ & $0.71-0.54$ & $0.66-0.57$ & $0.81-0.79$ & $0.65-0.58$ & $0.65-0.58$ & $0.70-0.57$ \\
\hline$\underline{\mathrm{PM}_{2.5}}$ & $0.67-0.5$ & $0.87-0.78$ & $0.87-0.78$ & $0.87-0.78$ & $0.87-0.78$ & $0.62-0.55$ & $0.88-0.79$ & $0.78-0.62$ & $0.71-0.59$ & $0.71-0.59$ & $0.71-0.60$ \\
\hline Absorbance $\mathrm{PM}_{2.5}$ & $0.65-0.4$ & $0.89-0.85$ & $0.89-0.85$ & 0.89-0.85 & $0.89-0.85$ & $0.92-0.86$ & $0.97-0.95$ & $0.91-0.82$ & $0.88-0.81$ & $0.88-0.81$ & $0.84-0.70$ \\
\hline $\mathrm{NO}_{2}$ & $0.83-0.7$ & $0.82-0.78$ & $0.82-0.78$ & $0.82-0.78$ & $0.82-0.78$ & $0.88-0.83$ & $0.89-0.84$ & $0.86-0.67$ & $0.78-0.70$ & $0.78-0.70$ & $0.87-0.76$ \\
\hline $\mathrm{NO}_{x}$ & $0.85-0.7$ & 0.83-0.79 & $0.83-0.79$ & 0.83-0.79 & $0.83-0.79$ & $0.83-0.73$ & $0.88-0.81$ & $0.88-0.76$ & $0.78-0.72$ & $0.78-0.72$ & $0.80-0.79$ \\
\hline
\end{tabular}

$\mathrm{PM}_{2.5}=$ particulate matter <2.5 $\mu \mathrm{m} ; \mathrm{PM}_{10}=$ particulate matter <10 $\mu \mathrm{m} ; \mathrm{NO}_{2}=$ nitrogen dioxide; $\mathrm{NOx}=$ nitrogen oxides. 
Table 4| Additional baseline characteristics of study populations in analysis of long term exposure to ambient air pollution and incidence of acute coronary events. Values are numbers (percentages) unless stated otherwise

\begin{tabular}{|c|c|c|c|c|c|c|c|c|c|c|c|}
\hline & \multirow[b]{2}{*}{ FINRISK } & \multirow[b]{2}{*}{ SNAC-K } & \multirow[b]{2}{*}{ SALT } & \multirow{2}{*}{$\begin{array}{l}60 \text { year } \\
\text { olds }\end{array}$} & \multirow[b]{2}{*}{ SDPP } & \multirow[b]{2}{*}{$\mathrm{DCH}$} & \multirow[b]{2}{*}{ HNR } & \multirow[b]{2}{*}{ KORA } & \multirow[b]{2}{*}{ EPIC Turin } & \multicolumn{2}{|c|}{ SIDRIA } \\
\hline & & & & & & & & & & Turin & Rome \\
\hline \multicolumn{12}{|c|}{ Area level socioeconomic indicators: } \\
\hline 1 (lowest) & - & $1429(53)$ & $1692(28)$ & $898(24)$ & $3024(39)$ & - & - & - & $963(13)$ & 1114 (22) & $2332(25)$ \\
\hline 2 & - & $1252(47)$ & $2643(43)$ & $924(25)$ & $1164(15)$ & - & - & - & $1404(19)$ & $1114(22)$ & $1802(20)$ \\
\hline 3 & - & $3(0)$ & $242(4)$ & $938(25)$ & $2016(26)$ & - & - & - & $1342(19)$ & $944(18)$ & $1675(18)$ \\
\hline 4 & - & - & $1507(25)$ & $926(25)$ & $1519(20)$ & - & - & - & $1662(23)$ & $1070(21)$ & $1684(18)$ \\
\hline 5 (highest) & - & - & - & - & - & - & - & - & $1859(26)$ & $895(17)$ & 1707 (19) \\
\hline Mean (SD) & $\begin{array}{l}22946 \\
(5458) \\
\end{array}$ & & & & & $1.9(0.4)$ & $12.6(3.1)$ & $28.1(18.4)$ & & & \\
\hline $\begin{array}{l}\text { Mean (SD) } \\
\text { BMI }\end{array}$ & $26.3(4.6)$ & $25.6(4.1)$ & $28.5(4.1)$ & $26.8(4.2)$ & $25.7(4.0)$ & $26.0(4.1)$ & $27.8(4.6)$ & $27.1(4.6)$ & $25.3(3.8)$ & - & - \\
\hline \multicolumn{12}{|c|}{ BMI in classes: } \\
\hline$<25$ & $4329(43)$ & $1209(48)$ & $1055(18)$ & $1349(37)$ & $3741(49)$ & $15998(45)$ & $1201(27)$ & $2824(34)$ & $3691(51)$ & - & - \\
\hline $25-29$ & $3852(39)$ & $1004(40)$ & $3131(52)$ & $1633(44)$ & $2995(39)$ & $14642(41)$ & $2025(46)$ & 3551 (43) & 2779 (38) & - & - \\
\hline$>29$ & $1811(18)$ & $302(12)$ & $1805(30)$ & $704(19)$ & $964(13)$ & $5026(14)$ & $1189(27)$ & $1852(23)$ & $761(11)$ & - & - \\
\hline \multicolumn{12}{|c|}{ Physical activity (hours/week): } \\
\hline$<1$ & $1808(18)$ & $464(20)$ & $1575(26)$ & $2510(69)$ & $846(11)$ & $15984(45)$ & $2263(51)$ & $3107(37)$ & $1660(23)$ & - & - \\
\hline$\sim 1$ & $3322(33)$ & $686(30)$ & $3757(62)$ & $858(24)$ & $6273(81)$ & $19709(55)$ & $490(11)$ & $3515(42)$ & $2032(28)$ & - & - \\
\hline$>2$ & $4839(49)$ & $1115(49)$ & $716(12)$ & $279(8)$ & $597(8)$ & - & $1667(38)$ & $1666(20)$ & $3538(49)$ & - & - \\
\hline \multicolumn{12}{|c|}{ Alcohol consumption (drinks/week): } \\
\hline Never & $1320(13)$ & $519(19)$ & - & $168(5)$ & $594(8)$ & $776(2)$ & $1015(23)$ & $3867(47)$ & $457(6)$ & - & - \\
\hline $1-3$ & $4566(46)$ & $634(24)$ & - & $771(21)$ & $2876(38)$ & $34142(98) \dagger$ & $1190(27)$ & $1212(15)$ & $201(3)$ & - & - \\
\hline $3-6$ & $3139(32)$ & $1236(46)$ & - & $1622(44)$ & $3873(51)$ & - & $2127(49)$ & $549(7)$ & $347(5)$ & - & - \\
\hline$>6$ & $824(8)$ & $288(11)$ & - & $1123(30)$ & $280(4)$ & - & & $2662(32)$ & $6225(86)$ & - & - \\
\hline \multicolumn{12}{|c|}{ Diabetes mellitus: } \\
\hline No & $9546(96)$ & $2464(92)$ & $5833(96)$ & $3533(96)$ & 7597 (98) & $34943(98)$ & $3877(87)$ & $7940(96)$ & $7118(98)$ & $5111(99)$ & $9179(100)$ \\
\hline Yes & $426(4)$ & $220(8)$ & $251(4)$ & $153(4)$ & $126(2)$ & $703(2)$ & $556(13)$ & $360(4)$ & $110(2)$ & $26(1)$ & $21(0)$ \\
\hline \multicolumn{12}{|c|}{ Hypertension: } \\
\hline No & $5877(59)$ & $902(34)$ & $4735(78)$ & $1770(48)$ & $5801(76)$ & $30033(84)$ & $2002(45)$ & $5098(62)$ & $3629(53)$ & $5082(99)$ & $9124(99)$ \\
\hline Yes & $4042(41)$ & $1762(66)$ & $1347(22)$ & $1915(52)$ & $1837(24)$ & $5625(16)$ & $2423(55)$ & $3190(38)$ & $3255(47)$ & $55(1)$ & $76(1)$ \\
\hline $\begin{array}{l}\text { Mean (SD) } \\
\text { serum } \\
\text { cholesterol }\end{array}$ & $211(78)$ & - & - & $231(41)$ & - & - & $231(39)$ & $229(44)$ & - & - & - \\
\hline \multicolumn{12}{|c|}{ Noise exposure at baseline address (dB): } \\
\hline$<45$ & & & $123(5)$ & $84(6)$ & - & $126(0)$ & $721(17)$ & $466(6)$ & $44(1)$ & $62(1)$ & - \\
\hline $45-49$ & $1912(23) \ddagger$ & $319(12)$ & $200(8)$ & $110(7)$ & - & $1838(5)$ & $989(23)$ & $1345(16)$ & $115(2)$ & $121(2)$ & - \\
\hline $50-54$ & $2040(24)$ & $799(30)$ & $524(21)$ & $292(20)$ & - & $9634(27)$ & $853(20)$ & $2946(36)$ & 87 (2) & $103(2)$ & - \\
\hline $55-59$ & $1721(21)$ & $692(26)$ & $550(23)$ & $304(21)$ & - & $9560(27)$ & $565(13)$ & $1873(23)$ & $253(5)$ & $186(4)$ & - \\
\hline $60-64$ & $1181(14)$ & $627(24)$ & $435(18)$ & $291(20)$ & - & $7625(21)$ & $482(11)$ & $987(12)$ & $2419(43)$ & $2237(44)$ & - \\
\hline $65-69$ & $784(9)$ & $230(9)$ & $332(14)$ & $225(15)$ & - & $4600(13)$ & $462(11)$ & $478(6)$ & $1254(22)$ & $1133(22)$ & - \\
\hline $70-74$ & $714(9) \ddagger$ & 0 & $237(10)$ & $143(10)$ & - & $2010(6)$ & $194(5)$ & $199(2)$ & $1369(24)$ & $1126(22)$ & - \\
\hline$>74$ & - & - & $43(2)$ & $30(2)$ & - & $294(1)$ & $40(1)$ & $3(0)$ & $136(2)$ & $156(3)$ & - \\
\hline \multicolumn{12}{|c|}{ Living in areas of low urbanisation: } \\
\hline No & $9086(91)$ & $2684(100)$ & $2763(45)$ & $1450(39)$ & $0(0)$ & $14155(40)$ & $4433(100)$ & $3557(43)$ & $7230(100)$ & $5137(100)$ & $9200(100)$ \\
\hline Yes & $909(9)$ & $0(0)$ & 3321 (55) & $2236(61)$ & $7723(100)$ & $21538(60)$ & $0(0)$ & $4744(57)$ & $0(0)$ & $0(0)$ & $0(0)$ \\
\hline
\end{tabular}

*FINRISK: median income rate in $3 \mathrm{~km}$ area; SNAC-K: mean income in thirds at small neighbourhood level (Small Area for Market Statistics); SALT and SDPP: mean income in four categories at municipality level; 60 years: mean income in quarters at small neighbourhood level (Small Area for Market Statistics); $\mathrm{DCH}$ : mean income at municipality level (16 units with median population of 1500 inhabitants), per/100 000; HNR: unemployment rate at neighbourhood level; KORA: percentage of low income in $5 \mathrm{~km}$ grid; EPIC-Turin, SIDRIA-Turin, and SIDRIA-Rome: deprivation index, census block level (average 500 inhabitants). 
Table 4 (continued)

\begin{tabular}{|c|c|c|c|c|c|c|c|c|c|c|}
\hline \multirow[b]{2}{*}{ FINRISK } & \multirow[b]{2}{*}{ SNAC-K } & \multirow[b]{2}{*}{ SALT } & \multirow{2}{*}{$\begin{array}{l}60 \text { year } \\
\text { olds }\end{array}$} & \multirow[b]{2}{*}{ SDPP } & \multirow[b]{2}{*}{ DCH } & \multirow[b]{2}{*}{ HNR } & \multirow[b]{2}{*}{ KORA } & \multirow[b]{2}{*}{ EPIC Turin } & \multicolumn{2}{|c|}{ SIDRIA } \\
\hline & & & & & & & & & Turin & Rome \\
\hline
\end{tabular}


Table 5| Association between exposure to pollutants and incidence of coronary events. Results expressed per fixed increments

\begin{tabular}{|c|c|c|c|c|c|c|}
\hline \multirow[b]{2}{*}{ Exposure } & \multirow[b]{2}{*}{ Fixed increment } & \multirow[b]{2}{*}{ Cohorts } & \multirow[b]{2}{*}{ Participants } & \multicolumn{3}{|c|}{ Pooled hazard ratios $(95 \% \mathrm{Cl})$} \\
\hline & & & & Model $1^{\star}$ & Model $2 \dagger$ & Model 3‡ \\
\hline $\mathrm{PM}_{10}\left(\mu \mathrm{g} / \mathrm{m}^{3}\right)$ & 10 & 11 & 100166 & 1.15 (1.04 to 1.28$)$ & 1.12 (1.01 to 1.24$)$ & $1.12(1.01$ to 1.25$)$ \\
\hline Coarse PM $\left(\mu \mathrm{g} / \mathrm{m}^{3}\right)$ & 5 & 11 & 100166 & 1.08 (1.00 to 1.17$)$ & $1.06(0.98$ to 1.14$)$ & 1.06 (0.98 to 1.15$)$ \\
\hline $\mathrm{PM}_{2.5}\left(\mu \mathrm{g} / \mathrm{m}^{3}\right)$ & 5 & 11 & 100166 & 1.22 (1.04 to 1.44$)$ & 1.15 (1.00 to 1.32$)$ & $1.13(0.98$ to 1.30$)$ \\
\hline Absorbance $\mathrm{PM}_{2.5}\left(10^{-5} / \mathrm{m}\right)$ & 1 & 11 & 100166 & 1.18 (1.05 to 1.32$)$ & $1.10(0.98$ to 1.24$)$ & $1.10(0.98$ to 1.24$)$ \\
\hline $\mathrm{NO}_{2}\left(\mu \mathrm{g} / \mathrm{m}^{3}\right)$ & 10 & 11 & 100166 & 1.04 (0.96 to 1.12$)$ & $1.03(0.96$ to 1.11$)$ & 1.03 (0.97 to 1.08$)$ \\
\hline $\mathrm{NO}_{x}\left(\mu \mathrm{g} / \mathrm{m}^{3}\right)$ & 20 & 11 & 100166 & $1.03(1.00$ to 1.07$)$ & $1.01(0.98$ to 1.05$)$ & 1.01 (0.98 to 1.05$)$ \\
\hline $\begin{array}{l}\text { Traffic intensity on nearest road adjusted for } \\
\text { background } \mathrm{NO}_{2} \text { (vehicles/day)§ }\end{array}$ & 5000 & 10 & 95733 & 1.01 (0.98 to 1.04$)$ & 1.01 (0.98 to 1.04$)$ & 1.01 (0.98 to 1.04 ) \\
\hline $\begin{array}{l}\text { Traffic load on major roads in } 100 \mathrm{~m} \text { buffer } \\
\text { adjusted for background } \mathrm{NO}_{2} \\
\text { (vehicles } \times \mathrm{m} / \text { day) }\end{array}$ & 4000000 & 11 & 100166 & $1.02(0.96$ to 1.08$)$ & $1.00(0.95$ to 1.06$)$ & $1.00(0.95$ to 1.06$)$ \\
\hline
\end{tabular}

*Adjusted for age (time variable), year of enrolment and sex

†As for model 1 plus adjusted for marital status, education, occupation, smoking status, smoking duration, and smoking intensity.

$\ddagger$ As for model 2 plus adjusted for socioeconomic area level variables.

$\S$ All cohorts except HNR study. ${ }^{24}$ 
Table 6 | Incidence of coronary events, results from sensitivity analyses. Figures are pooled hazard ratios (and $95 \% \mathrm{Cl}$ ) for $10 \mu \mathrm{g} / \mathrm{m}^{3} \mathrm{PM} 10$ and $5 \mu \mathrm{g} / \mathrm{m}^{3}$ PM2.5, $\mathrm{I}^{2}$ statistics, and $\mathrm{P}$ value for heterogeneity

\begin{tabular}{|c|c|c|c|c|}
\hline \multirow[b]{2}{*}{ Model } & \multirow[b]{2}{*}{ No of cohorts } & \multirow[b]{2}{*}{ No of participants* } & \multicolumn{2}{|c|}{ Hazard ratio† $(95 \% \mathrm{Cl})$} \\
\hline & & & $10 \mu \mathrm{g} / \mathrm{m}^{3} \mathrm{PM}_{10}$ & $5 \mu \mathrm{g} / \mathrm{m}^{3} \mathrm{PM}_{2.5}$ \\
\hline Base model (model 3) & 11 & 100166 & $1.12(1.01$ to 1.25$)$ & $1.13(0.98$ to 1.30$)$ \\
\hline \multicolumn{5}{|l|}{ Role of cardiovascular risk factors } \\
\hline \multicolumn{5}{|c|}{ Intermediate variables: diabetes and hypertension: } \\
\hline + diabetes and hypertension & 11 & 99526 & $1.11(1.00$ to 1.24$)$ & $1.11(0.96$ to 1.28$)$ \\
\hline \multicolumn{5}{|l|}{ Physical activity, alcohol and BMlł: } \\
\hline $\begin{array}{l}\text { Base model, on subset of participants with } \\
\text { additional information }\end{array}$ & 8 & 77584 & $1.17(1.04$ to 1.33$)$ & $1.22(1.03$ to 1.44$)$ \\
\hline + additional information & 8 & 77584 & $1.17(1.04$ to 1.33$)$ & $1.19(1.01$ to 1.42$)$ \\
\hline \multicolumn{5}{|c|}{ All cardiovascular risk factors (diabetes, hypertension, physical activity, alcohol, BMI, cholesterol)§: } \\
\hline $\begin{array}{l}\text { Base model, on subset of participants with } \\
\text { additional information }\end{array}$ & 4 & 25625 & $1.19(0.92$ to 1.53$)$ & $1.28(0.92$ to 1.79$)$ \\
\hline + additional information & 4 & 25625 & $1.20(0.93$ to 1.56$)$ & $1.29(0.92$ to 1.81$)$ \\
\hline \multicolumn{5}{|l|}{ Urban/suburban-rural residence location: } \\
\hline $\begin{array}{l}\text { Base model, on subset of participants with } \\
\text { additional information }\end{array}$ & 11 & 100166 & $1.12(1.01$ to 1.25$)$ & $1.13(0.98$ to 1.39$)$ \\
\hline + additional information & 11 & 100166 & $1.13(1.02$ to 1.26$)$ & $1.14(0.99$ to 1.31$)$ \\
\hline \multicolumn{5}{|l|}{ Noiseף: } \\
\hline $\begin{array}{l}\text { Base model, on subset of participants with } \\
\text { noise information }\end{array}$ & 9 & 73840 & $1.14(1.01$ to 1.30$)$ & $1.16(0.98$ to 1.37$)$ \\
\hline+ noise variable & 9 & 73840 & $1.14(1.01$ to 1.31$)$ & $1.13(0.95$ to 1.36$)$ \\
\hline \multicolumn{5}{|l|}{ Change of address $^{\star \star}:$} \\
\hline $\begin{array}{l}\text { Base model, on subset of cohorts with } \\
\text { change of address information }\end{array}$ & 10 & 92936 & 1.11 (0.99 to 1.23$)$ & $1.14(0.98$ to 1.33$)$ \\
\hline $\begin{array}{l}\text { Participants who didn't change address } \\
\text { during follow-up }\end{array}$ & 10 & 63121 & $1.16(1.01$ to 1.32$)$ & 1.18 (0.98 to 1.42$)$ \\
\hline \multicolumn{5}{|l|}{ Proportionality hazards (PH) assumption: } \\
\hline Variables that do not meet $\mathrm{PH}$ put as strata & 11 & 100166 & $1.10(0.99$ to 1.23$)$ & $1.13(0.98$ to 1.30$)$ \\
\hline \multicolumn{5}{|l|}{ Exclusion of DCH Study } \\
\hline Data after exclusion & 10 & 64473 & $1.12(0.99$ to 1.27$)$ & $1.09(0.92$ to 1.30$)$ \\
\hline \multicolumn{5}{|c|}{ Performance of land use regression modeltt: } \\
\hline Leave one out cross validation $\mathrm{R}^{2}>60 \%$ & - & - & $1.18(1.05$ to 1.33$)$ & 1.35 (1.04 to 1.74$)$ \\
\hline Leave one out cross validation $\mathrm{R}^{2} \leq 60 \%$ & - & - & 0.88 (0.68 to 1.12$)$ & 1.05 (0.89 to 1.25$)$ \\
\hline
\end{tabular}

${ }^{*}$ Figures depend on number of cohorts included and on missing values of included variables

†Adjusted for age (time variable), year of enrolment, sex, marital status, education, occupation, smoking status, smoking duration, smoking intensity, and socioeconomic area level indicators.

‡Excludes SALT, SIDRIA-Turin, and SIDRIA-Rome.

§Includes FINRISK, 60 year olds, HNR, and KORA.

IAll cohorts except SDPP and SIDRIA-Rome.

${ }^{* *}$ All cohorts except EPIC-Turin.

††For $\mathrm{PM}_{10}$ : nine cohorts, 80971 participants (excludes FINRISK and SIDRIA-Rome). For $\mathrm{PM}_{2.5}$ : six cohorts, 42906 participants (excludes FINRISK, DCH, EPIC-Turin, SIDRIA-Turin, and SIDRIA-Rome). 
Table 7| Results from random-effects meta-analyses for adjusted association between incidence of coronary events and exposure to PM10 and PM2.5 below various threshold values. Figures are pooled hazard ratios $(95 \% \mathrm{Cl})$ for $10 \mu \mathrm{g} / \mathrm{m}^{3} \mathrm{PM} 10$ and $5 \mu \mathrm{g} / \mathrm{m}^{3} \mathrm{PM} 2.5, \mathrm{I}^{2} \mathrm{statistic}$, and $P$ value for heterogeneity

\begin{tabular}{|c|c|c|c|c|c|c|c|c|c|c|}
\hline \multirow{2}{*}{$\begin{array}{l}\text { Exposure } \\
\text { and } \\
\text { threshold }\end{array}$} & \multicolumn{5}{|c|}{ Cohorts with exposure data available for respective threshold } & \multicolumn{5}{|c|}{ Cohorts with exposure data available for all thresholds } \\
\hline & $\begin{array}{l}\text { No of } \\
\text { cohorts }\end{array}$ & $\begin{array}{c}\text { No of } \\
\text { participants }\end{array}$ & $\mathrm{HR}^{*}(95 \% \mathrm{Cl})$ & $I^{2}$ & $P$ value & $\begin{array}{l}\text { No of } \\
\text { cohorts }\end{array}$ & $\begin{array}{c}\text { No of } \\
\text { participants }\end{array}$ & $\mathrm{HR}^{\star}(95 \% \mathrm{Cl})$ & $I^{2}$ & $P$ value \\
\hline \multicolumn{11}{|l|}{$\mathrm{PM}_{10}\left(\mu \mathrm{g} / \mathrm{m}^{3}\right):$} \\
\hline $\begin{array}{l}\text { Full range of } \\
\text { exposure }\end{array}$ & - & - & - & - & - & $7 \dagger$ & 74166 & $\begin{array}{c}1.15 \text { (1.02 to } \\
1.30)\end{array}$ & 0 & 0.92 \\
\hline$<20$ & $7 \dagger$ & 64363 & $\begin{array}{c}1.20(1.01 \text { to } \\
1.41)\end{array}$ & 0 & 0.91 & $7 \dagger$ & 64363 & $\begin{array}{c}1.20(1.01 \text { to } \\
1.41)\end{array}$ & 0 & 0.91 \\
\hline$<30$ & $8 \ddagger$ & 77997 & $\begin{array}{c}1.12(0.98 \text { to } \\
1.27)\end{array}$ & 0 & 0.94 & $7 \dagger$ & 74019 & $\begin{array}{c}1.12(0.98 \text { to } \\
1.27)\end{array}$ & 0 & 0.91 \\
\hline$<40$ & $9 \S$ & 86222 & $\begin{array}{c}1.12(1.00 \text { to } \\
1.27)\end{array}$ & 0 & 0.48 & $7 \dagger$ & 74166 & $\begin{array}{c}1.15(1.02 \text { to } \\
1.30)\end{array}$ & 0 & 0.92 \\
\hline \multicolumn{11}{|l|}{$\mathrm{PM}_{2.5}\left(\mu \mathrm{g} / \mathrm{m}^{3}\right):$} \\
\hline $\begin{array}{l}\text { Full range of } \\
\text { exposure }\end{array}$ & - & - & - & - & - & $7 \dagger$ & 74166 & $\begin{array}{c}1.23(1.04 \text { to } \\
1.46)\end{array}$ & 0 & 0.57 \\
\hline$<15$ & $7 \dagger$ & 73420 & $\begin{array}{c}1.19(1.00 \text { to } \\
1.42)\end{array}$ & 0 & 0.74 & $7 \dagger$ & 73420 & $\begin{array}{c}1.19(1.00 \text { to } \\
1.42)\end{array}$ & 0 & 0.74 \\
\hline$<20$ & $9 \S$ & 85216 & $\begin{array}{c}1.17(0.91 \text { to } \\
1.50)\end{array}$ & 30 & 0.18 & $7 \dagger$ & 74166 & $\begin{array}{c}1.23(1.04 \text { to } \\
1.46)\end{array}$ & 0 & 0.57 \\
\hline$<25$ & $9 \S$ & 87532 & $\begin{array}{c}1.18 \text { (1.01 to } \\
1.39)\end{array}$ & 0 & 0.56 & $7 \dagger$ & 74166 & $\begin{array}{c}1.23(1.04 \text { to } \\
1.46)\end{array}$ & 0 & 0.57 \\
\hline
\end{tabular}

*Adjusted for age (time variable), year of enrolment, sex, marital status, education, occupation, smoking status, smoking duration, smoking intensity. and socioeconomic area level indicators

†All cohorts except Heinz Nixdorf Recall Study, EPIC-Turin, SIDRIA-Turin and SIDRIA-Rome. $\ddagger$ All cohorts except EPIC-Turin, SIDRIA-Turin and SIDRIA-Rome.

§All cohorts except EPIC-Turin and SIDRIA-Turin. 


\section{Figure}

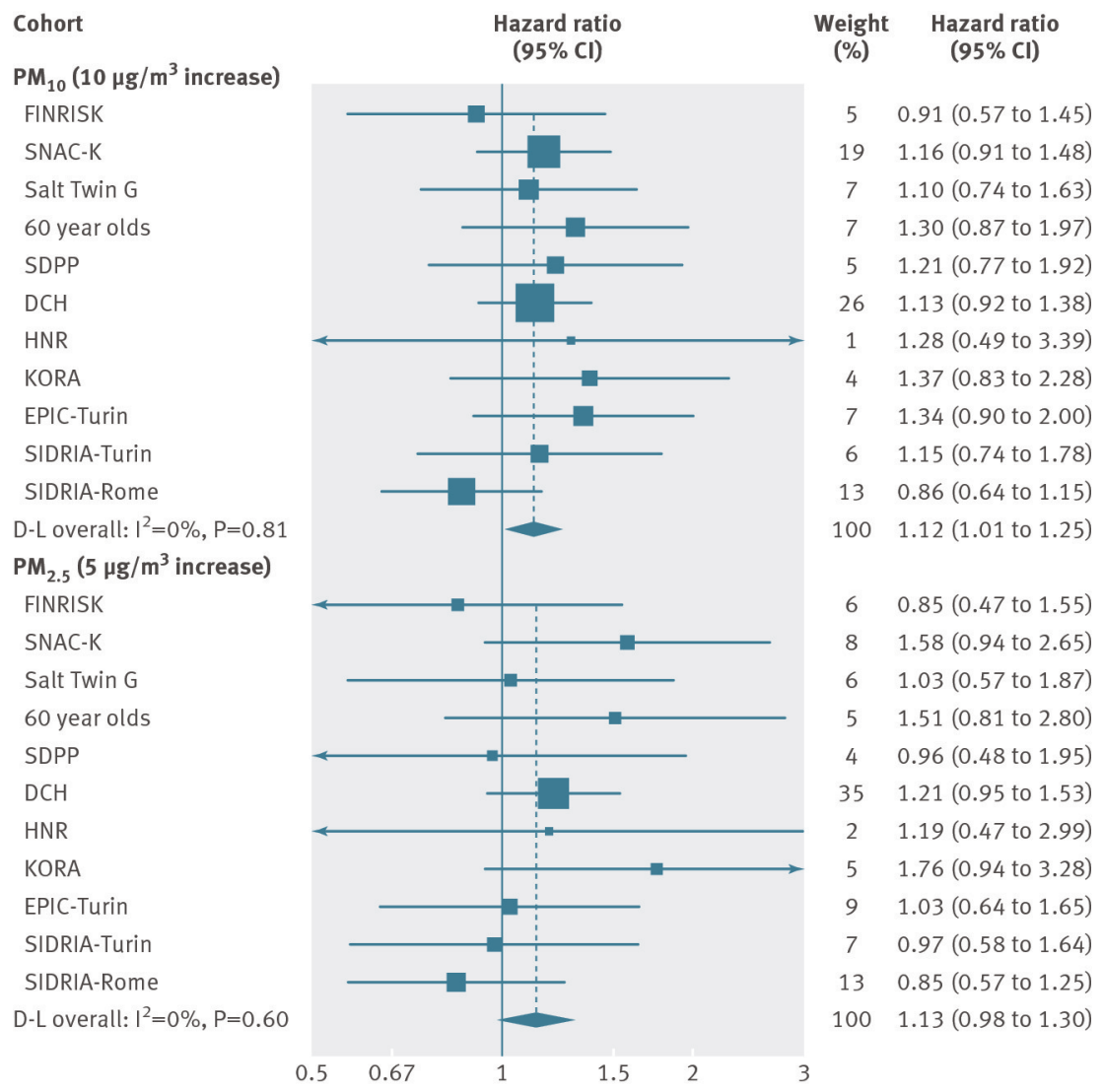

Hazard ratios of incident coronary events per $10 \mu \mathrm{g} / \mathrm{m}^{3} \mathrm{PM}_{10}$ and $5 \mu \mathrm{g} / \mathrm{m}^{3} \mathrm{PM}_{2.5}$. Cohort specific and meta-analytic results 